\title{
BIOCLIMATOLOGICAL RATING OF CITIES AND RESORTS IN SOUTH AFRICA ACCORDING TO THE CLIMATE INDEX
}

\author{
S. BECKER* \\ Justus-Liebig-University, Department of Geography, Senckenbergstr. 1, 35390 Gießen, Germany
}

Received 14 October 1997

Revised 7 December 1999

Accepted 7 December 1999

\begin{abstract}
The climatic conditions of 31 cities and resorts in South Africa have been examined with regard to the thermal perception of people. The evaluation of the thermal conditions is based on the human energy balance calculations, which have been specified for the detection of hot or cold discomfort of people walking outdoors in spite of adapted clothing. Hot days and cold days are defined depending on the extent and duration of thermal discomfort. Cities are rated according to the Climate Index (CI), which is defined in terms of the monthly frequency of hot or cold days. The most pleasant conditions in the annual average can be found along the coastal belt (Port St. Johns, Richards Bay, St. Lucia), the most unpleasant ones in the mediterranean region around Cape Town, the Karoo and the eastern lowveld. Copyright (C) 2000 Royal Meteorological Society.
\end{abstract}

KEY wORDS: bioclimatology; Fanger equation; heat stress; PMV; South Africa

\section{INTRODUCTION}

The climatic conditions with regard to the human perception contribute considerably to the living quality of cities. Cities have been rated and ranked all over the world according to a set of criteria, which include aspects like 'number of inhabitants', 'living standard', 'living expenses', 'economical power' and others. The aim of this study is to provide a model for the evaluation of the thermal bioclimatic conditions of a city based on the Fanger (1972) comfort equation (see Section 2) and apply this model to cities and resorts in South Africa. Terjung (1966) and Auliciems and Kalma (1979) provide evaluations and classifications of thermal stress for humans in the US and Australia. Jendritzky et al. $(1979,1990)$ provide a key to evaluate thermal environmental conditions of cities using six classes to describe the frequency of the events 'heat stress' or 'cold discomfort'. Seidl (1990) published a biometeorological evaluation of mediterranean holiday resorts based on the degree of heat or cold stress. A complete bioclimatic evaluation of a location requires, in addition to the assessment of the thermal environmental conditions, the analysis of the actinic conditions as well as air chemistry (Ahlheim, 1989). The climatic rating provided in this study is confined to the thermal conditions due to the availability of data. The evaluation of the thermal conditions is also strictly speaking only valid for the location of the weather station, whereas variations occur depending on factors like altitude, slope orientation, height and density of buildings, underground surface and others. However, these variations are small in comparison with the bioclimatic differences between the cities, so that the results can be considered as representative for the average city climates.

\footnotetext{
* Correspondence to: Justus-Liebig-University, Department of Geography, Senckenbergstr. 1, 35390 Gießen, Germany.
} 


\section{CALCULATION OF THE THERMAL PERCEPTION}

The impact of thermal conditions on the well-being of people has been the subject of numerous studies under different aspects in the past. Various authors relate the thermal perception of people or the thermal stress exposure to climatic parameters using different models. Scharlau (1950), King (1951), Leistner (1951), Thom (1959) and Sohar (1980) use simple empirical relations to relate thermal perception to dry bulb temperature, wet bulb temperature and wind speed. Fanger (1972), Givoni (1976), Höppe (1984), de Freitas (1985) and Jendritzky et al. (1990) point out the complex effects of numerous parameters on the human thermo regulation system and provide human energy balance models. The application of these energy balance models enables the calculation of the average thermal perception of a group of people in certain places during certain activities, based on the availability of the climatic input data (see Section 3). The quantification of the thermal environmental conditions of humans according to the human energy balance equation is based on the first law of thermodynamics. Within this equation all energy fluxes that affect the thermal balance of humans are considered (Fanger, 1972; Höppe, 1984; de Freitas, 1985; Jendritzky et al., 1990). Figure 1 shows the components that influence the human energy balance system.

Fanger (1972) developed the comfort equation based on the assumption that thermal comfort is connected to a minimum of activities of the human thermo regulation system.

$$
\mathrm{PMV}=(0.028+0.202 * \operatorname{Exp}(-0.036 \mathrm{Met} / A)) *\left(\left(H-E_{\mathrm{d}}-E_{\mathrm{sw}}-E_{\mathrm{re}}-C-R\right) / A\right)
$$

where PMV is the predicted mean vote (measure for thermal perception, see Table I), Met is the metabolic rate, $A$ is the body surface, $H$ is the inner heat produced by metabolism. The calculations of the parameters $E_{\mathrm{d}}, E_{\mathrm{sw}}, E_{\mathrm{re}}, C$ and $R$ mainly depend on the metabolic rate as well as on various meteorological parameters (see Figure 1 for definitions). They are discussed in Fanger (1972), Höppe (1984), Jendritzky et al. (1990) and Becker (1996).

Thermal discomfort is defined as a fictitious deviation of the energy balance from ' 0 '. It is a fictitious deviation, because skin temperature and sweat rate are not calculated for the real but for comfortable conditions, where they only depend on the inner heat production. Fanger proved that the extent of the calculated deviation is closely connected to the extent of thermal stress perception of people and to the percentage of persons in thermal discomfort. Table I shows the correlation between the calculated

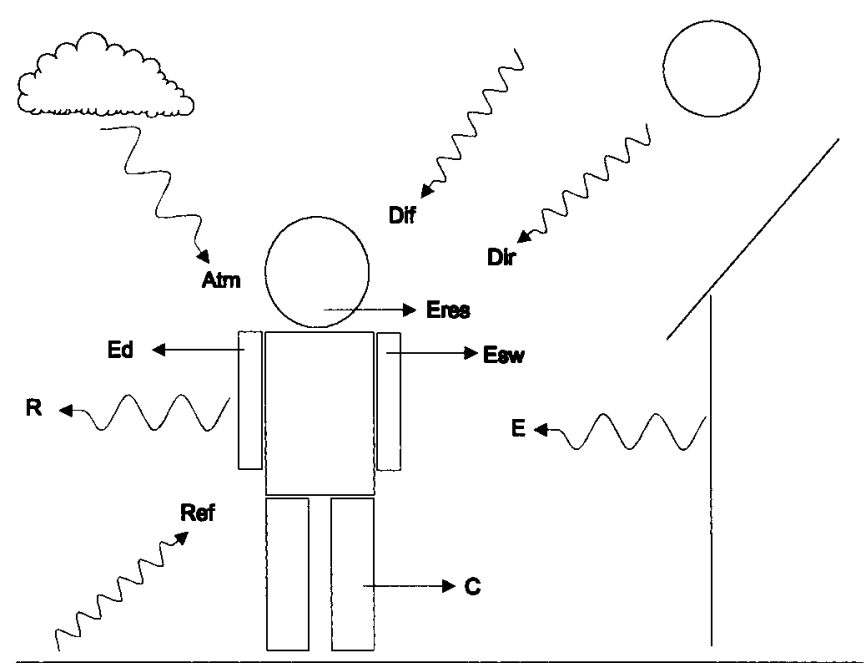

Figure 1. Components of the energy balance of man (Jendritzky et al., 1990). C, convective and conductive heat flux; $E_{\mathrm{d}}$, latent energy flux by vapour diffusion; $E_{\mathrm{sw}}$, latent energy flux by sweat evaporation (perspiration); $E_{\mathrm{res}}$, energy flux by respiration; Atm, long-wave atmospheric counter radiation; Dir, direct solar radiation; Dif, diffuse radiation; Ref, short-wave reflected radiation; $R$, long-wave radiation of humans; $E$, Long-wave radiation from surrounding areas 
Table I. Relation of PMV, thermal perception and percentage of persons in thermal discomfort

\begin{tabular}{lll}
\hline PMV & Thermal perception & $\begin{array}{l}\text { Persons in } \\
\text { discomfort }(\%)\end{array}$ \\
\hline$<-2.5$ & Severe cold stress & $>80$ \\
$-1.5--2.5$ & Medium cold stress & $>50$ \\
$-0.5--1.5$ & Light cold stress & $>10$ \\
$-0.5-0.5$ & Comfortable & $<10$ \\
$0.5-1.5$ & Light heat stress & $>10$ \\
$1.5-2.5$ & Medium heat stress & $>50$ \\
$>2.5$ & Severe heat stress & $>80$ \\
\hline
\end{tabular}

deviation and the extent of thermal stress, sub-divided into light, medium and severe stress and the percentage of persons in thermal discomfort.

Recent research outlines the weaknesses of applying a steady state heat exchange equation like the Fanger equation to variable environments (Humphreys in Oseland and Humphreys, 1993) and promotes the use of an adaptive model as presented by de Dear et al. (1997). The parameters 'thermal expectation' and 'seasonal adjustment' seem especially to play an important role in the thermal perception of people. Wyon (in Oseland and Humphreys, 1993) points out that these factors - which also vary depending on race, culture and adaptation-obviously do not lead to greatly different perceptions of thermally comfortable conditions, but rather to different interpretations of thermally discomfortable environments. This study mainly aims at the calculation and interpretation of the appearance and duration of thermal comfort and not the different levels of thermal discomfort. Therefore, the steady state equation of Fanger is, despite its inadequacies, well suited to describe the thermal conditions of cities as presented within this study.

\subsection{Adaptation of the energy balance model}

The calculation of the thermal perception according to Fanger's energy balance model requires the adjustment of the following constants.

- The metabolic rate (Met) of a person depends on the persons' activity, sex, size, weight and age (Kleiber, 1967; Fanger, 1972; Höppe, 1984). Jendritzky et al. (1990) calculate with a standardized person (Klima Michel — sex: male; height: $1.75 \mathrm{~cm}$; weight: $75 \mathrm{~kg}$; age: 35 years). This standardization is criticized (Mayer, 1986) as it does not consider interpersonal differences. However, considering that the human thermal perception can also be modified by many other physiological and psychological factors (Ganong, 1971; Weihe, 1985), a standardization allows the most meaningful thermal environmental comparisons. The metabolic rate has been standardized on $220 \mathrm{~W} / \mathrm{m}^{2}$ for a person walking at $3.2 \mathrm{~km} / \mathrm{h}$ on a flat ground.

- The long-wave radiation emission coefficient for the human body, which is necessary to calculate its heat loss by radiation $(R)$, is approximately 1.0 for the skin (Hardy and Muschenheim, 1934; Mitchell, 1970 ) and approximately 0.95 for clothing (Fanger, 1972). Jendritzky et al. (1990) used the average value 0.97 . For this study, a long-wave radiation emission coefficient value of 0.97 has been used for the person in summer clothes and 0.95 for the person in winter clothes.

- The insulation factor of the clothing $\left(I_{\mathrm{cl}}\right)$ has been standardized to 0.5 for the light summer clothing and on 1.5 for the winter clothing according to Jendritzky et al. (1990). The factor $\left(f_{\mathrm{cl}}\right)$ that describes the covered body surface to uncovered body surface has been fixed to 1.1 for summer and to 1.2 for winter.

- The emission coefficients for the surface, which are necessary to calculate the radiation fluxes of the environment and the heat loss of the human body by radiation $(R)$ have been resolved to 0.9 for long-wave and 0.3 for short-wave radiation (Paltridge and Platt, 1976). 
- The wind speed is calculated for the physiological relevant height of $1.5 \mathrm{~m}$ above ground by using the Hellmann formula for wind speed-height relations (Hellmann, 1917). The wind profile exponent has been fixed at 0.33 for urban areas.

- The body surface $(A)$ has been standardized to $1.9 \mathrm{~m}^{2}$, which represents for example a human with a size of $1.75 \mathrm{~m}$ and a bodyweight of $75 \mathrm{~kg}$ according to the formula of Dubois (in Höppe, 1984).

\section{DATA BASE}

Calculations of the human energy balance according to the above mentioned model require the following data: air temperature, humidity, wind speed, direct sun radiation, diffuse radiation and long-wave atmospheric counter radiation. The measuring increment should not exceed $3 \mathrm{~h}$ (minimum eight measurements per day) to enable the capture of the daily course of the data and to allow the calculation of daily durations of certain characteristics. Temperature, humidity, wind speed and solar radiation data were available from 1983 to 1993 on a 3-h basis. Cloud cover data were generally limited to three observations per day $(08: 00 \mathrm{~h}, 14: 00 \mathrm{~h}$ and 20:00 h) and were interpolated with an average accuracy of 0.2 oktas. Missing data were interpolated with average accuracy of less than $1.5^{\circ} \mathrm{C}$ (air temperature), $10 \%$ humidity, $2 \mathrm{~m} / \mathrm{s}$ (wind speed), $80 \mathrm{~W} / \mathrm{m}^{2}$ (direct solar radiation) and $40 \mathrm{~W} / \mathrm{m}^{2}$ (diffuse radiation). Formulas and calculated accuracies of these interpolations originate from the multiple regression analysis of the complete data sets. The long-wave atmospheric counter radiation is calculated according to Kasten (1989).

\section{BIOCLIMATIC EVALUATION}

\subsection{Definitions and calculations}

Climatic evaluations are always connected to generalizations when a huge amount of input data is processed and condensed to a few output data in order to provide understandable, interpretable and meaningful information. It is the aim of this study to define and calculate parameters, which are based on the huge amount of bioclimatically significant input data (eight data of thermal perception of people in different clothes during various activities per day), which has been processed in a way in which the output information is interpretable. Figure 2 shows a schematic representation of the bioclimatic analysis of this study.

The bioclimatic evaluation of cities and locations in South Africa is based on the frequency of heat stress and cold discomfort events. The generalization in this study is done in two steps: firstly, the parameters 'hot day' (HD) and 'cold day' (CD) are defined to provide information on the events mentioned above on a monthly basis, and secondly, in a further step, the frequency of these events are expressed by the Climate Index (CI), which does not differentiate any more between hot or cold discomfort.

Heat stress is quantified by the parameter ' $\mathrm{HD}=$ average number of days with more than $3 \mathrm{~h}$ of severe heat stress (PMV $>2.5)^{\prime}$ ' for a person walking in the sun in summer clothes. The occurrence of an event according to this definition means that people are exposed to extreme heat stress not only for a short peak period around noon but also in the morning or in the afternoon. Cold discomfort is quantified by the parameter ' $\mathrm{CD}=$ average number of days with more than $16 \mathrm{~h}$ of light cold discomfort $(\mathrm{PMV}<-0.5)$ ' for a person walking in the shade in winter clothes. The occurrence of an event according to this definition means that people are exposed to cold discomfort not only during the night but also during the day.

The calculation of the thermal perception of people in summer and winter clothes is limited to the eight daily measuring events. The temporal course of the thermal perception between the measuring events is calculated by linear regression. The following formula allows the determination of the start and end of the 


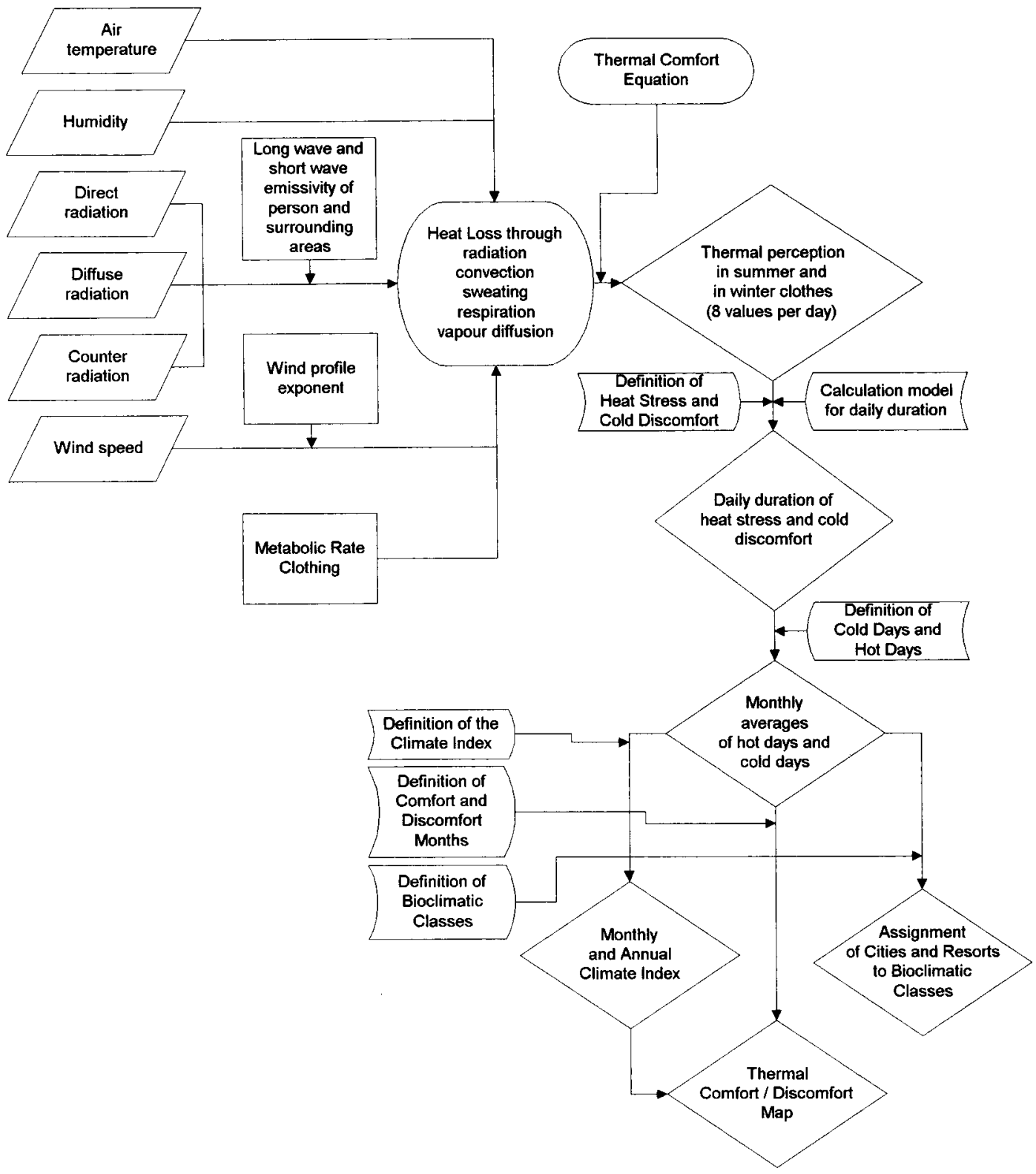

Figure 2. Schematic representation of the bioclimatological analysis in this study

discomfort time for every day (see Figure 3) and thus the calculation of the heat stress or cold discomfort durations and finally the HD and $\mathrm{CD}$ on a monthly or yearly basis.

$$
T=\left(\left(\mathrm{PMV}_{\text {thres }}-\mathrm{PMV}_{1}\right) *\left(T_{2}-T_{1}\right)\right) /\left(\left(\mathrm{PMV}_{2}-\mathrm{PMV}_{1}\right)+T_{1}\right)
$$

with $T=$ start or finish of the discomfort time; $\mathrm{PMV}_{\text {thres }}=$ threshold value: +2.5 for heat stress and -0.5 for cold discomfort; $T_{2}=$ earliest hour with $\mathrm{PMV}>\mathrm{PMV}_{\text {thres }}$ for calculation of start time and earliest hour with $\mathrm{PMV}<\mathrm{PMV}_{\text {thres }}$ for finish time; $T_{1}=T_{2}-3 \mathrm{~h} ; \mathrm{PMV}_{2}=\mathrm{PMV}$ at $T_{2} ; \mathrm{PMV}_{1}=\mathrm{PMV}$ at $T_{1}$.

Table II presents a model to differentiate the thermal environmental conditions in nine bioclimatological classes, which is in accordance with the maximum monthly occurrence of hot days in summer and cold days in winter. 


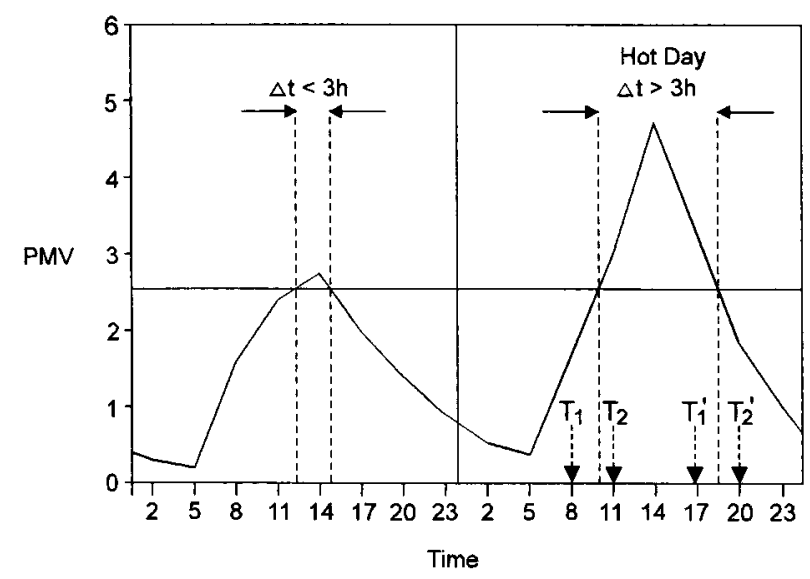

Figure 3. Concept of the calculation of hot days

Table II. Bioclimatological classes

\begin{tabular}{|c|c|c|c|c|}
\hline Class & $\mathrm{HD}(\mathrm{s})$ & $\mathrm{CD}(\mathrm{w})$ & Description & Locations \\
\hline I & $0-10$ & $0-10$ & $\begin{array}{l}\text { Little heat stress in summer, little cold } \\
\text { discomfort in winter }\end{array}$ & Port St. Johns \\
\hline II & $10-20$ & $0-10$ & $\begin{array}{l}\text { Medium heat stress in summer, little cold } \\
\text { discomfort in winter }\end{array}$ & $\begin{array}{l}\text { Durban, St. Lucia, Nelspruit, Richards } \\
\text { Bay, Port Shepstone }\end{array}$ \\
\hline III & $20-30$ & $0-10$ & $\begin{array}{l}\text { Severe heat stress in summer, little cold } \\
\text { discomfort in winter }\end{array}$ & Skukuza \\
\hline IV & $0-10$ & $10-20$ & $\begin{array}{l}\text { Little heat stress in summer, medium } \\
\text { cold discomfort in winter }\end{array}$ & $\begin{array}{l}\text { Alexander Bay, George, East London, } \\
\text { Port Elizabeth }\end{array}$ \\
\hline V & $10-20$ & $10-20$ & $\begin{array}{l}\text { Medium heat stress in summer, medium } \\
\text { cold discomfort in winter }\end{array}$ & Fort Beaufort, Pietersburg, Uitenhaage \\
\hline VI & $20-30$ & $10-20$ & $\begin{array}{l}\text { Severe heat stress in summer, medium } \\
\text { cold discomfort in winter }\end{array}$ & $\begin{array}{l}\text { Graaf Reinet, Kimberley, Upington, } \\
\text { Porterville, Potchefstrom, Pretoria }\end{array}$ \\
\hline VII & $0-10$ & $20-30$ & $\begin{array}{l}\text { Little heat stress in summer, severe cold } \\
\text { discomfort in winter }\end{array}$ & Cape Agulhas, Cape Columbine \\
\hline VIII & $10-20$ & $20-30$ & $\begin{array}{l}\text { Medium heat stress in summer, severe } \\
\text { cold discomfort in winter }\end{array}$ & Bethlehem, Cape Town, Johannesburg \\
\hline IX & $20-30$ & $20-30$ & $\begin{array}{l}\text { Severe heat stress in summer, severe cold } \\
\text { discomfort in winter }\end{array}$ & $\begin{array}{l}\text { Bloemfontein, Fraserburg, Worcester, } \\
\text { Grootfontein, Hawequas, Malmesbury }\end{array}$ \\
\hline
\end{tabular}

$\mathrm{HD}(\mathrm{s})$ : maximum number of hot days per month in summer; $\mathrm{CD}(\mathrm{w})$ : maximum number of cold days per month in winter.

The CI is a rating for the climate quality of a city or resort as related to the thermal perception of people. The higher the frequency of unpleasant events (hot days or cold days), the lower the rating on the scale from 0 to 10 . The $\mathrm{CI}$ is defined as follows:

$$
\mathrm{CI}_{(\text {month })}=\left(-\left(\mathrm{HD}_{(\text {month })}+\mathrm{CD}_{(\text {month })}\right) / 3\right)+10
$$

The CI is based on the monthly sum of HD and CD, which is converted to a scale ranging from 0 to 10 . According to the definition, a CI of 10 indicates that neither hot nor cold days are to be expected, whereas a CI of 0 indicates 30 hot or cold days (see Table III).

The annual $\mathrm{CI}$ is defined as the arithmetic mean value of the monthly CI values

$$
\mathrm{CI}=\sum \mathrm{CI}_{(\text {month) }} / 12
$$


Table III. Relation between CI and the number of HD or CD

\begin{tabular}{rl}
\hline CI & $\begin{array}{c}\text { Number of } \\
\text { HD or CD }\end{array}$ \\
\hline 0 & 30 \\
1 & 27 \\
2 & 24 \\
3 & 21 \\
4 & 18 \\
5 & 15 \\
6 & 12 \\
7 & 9 \\
8 & 6 \\
9 & 3 \\
10 & 0 \\
\hline
\end{tabular}

\subsection{Bioclimatic rating of cities and resorts in South Africa}

The analysis of the data of 31 cities (locations see Figures 4 and 5) and resorts in South Africa shows a variety of different thermal bioclimatic conditions, ranging from little discomfort in summer and winter (Port St. Johns with less than 10 monthly HD or CD) to frequent summer heat stress and winter cold discomfort in Bloemfontein, Fraserburg, Worcester, Grootfontein, Hawequas and Malmesbury (Table II).

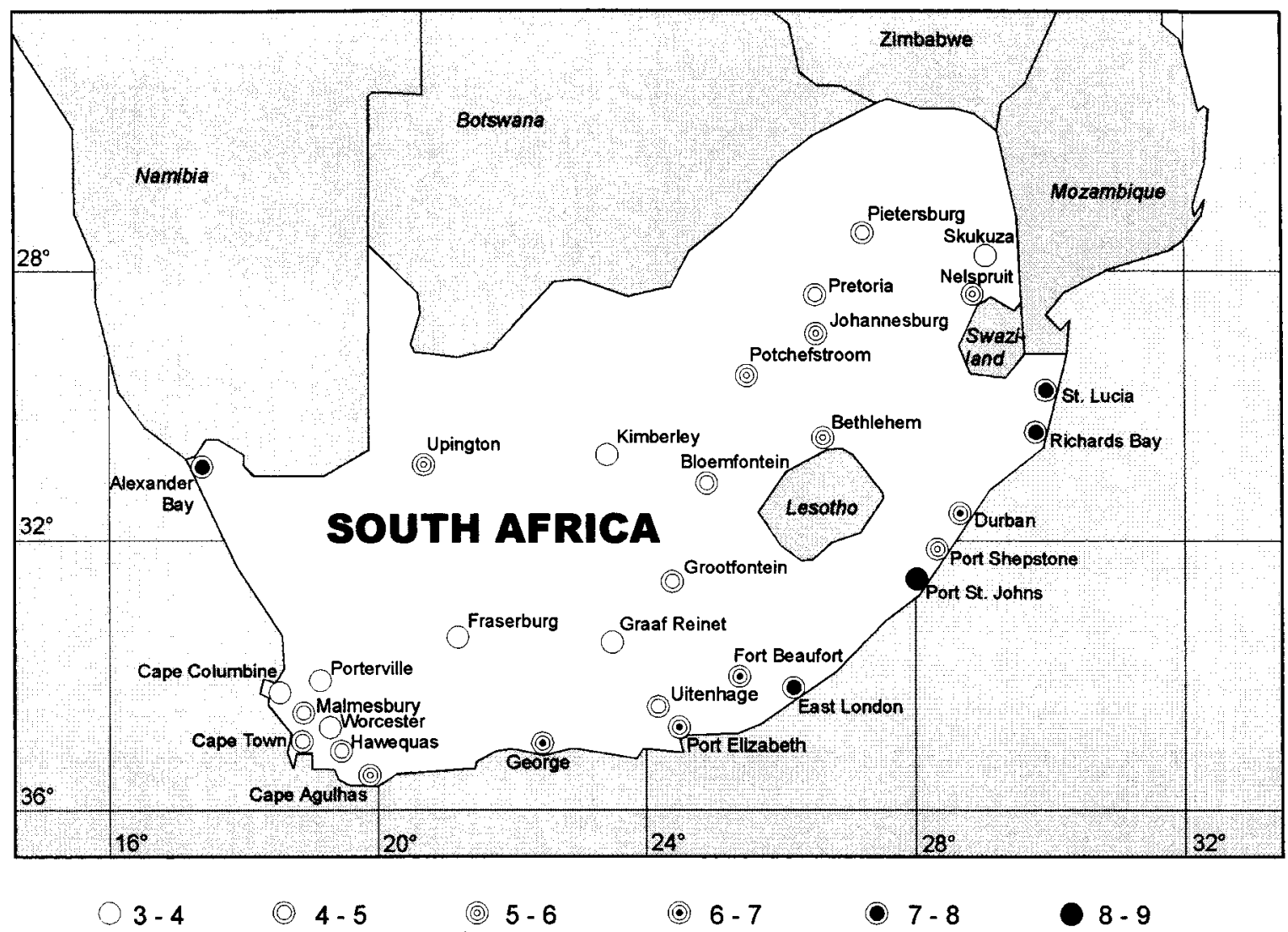

Figure 4. Annual climate data 


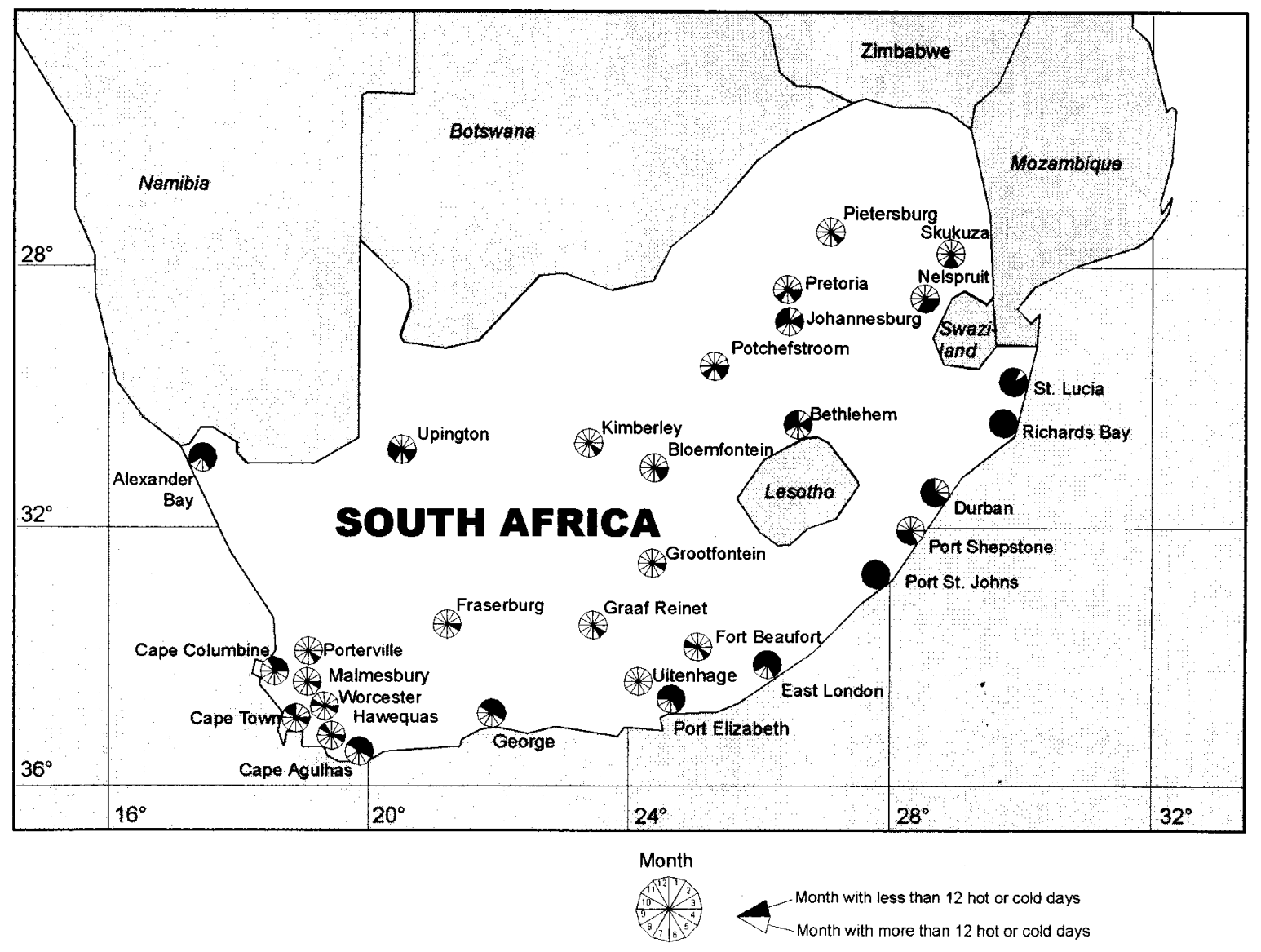

Figure 5. Thermal comfort/discomfort on a monthly basis

Skukuza is the station with frequent HD in summer ( $>20$ days/month) but hardly any CD in winter ( $<10$ days/month), whereas Cape Agulhas and Cape Columbine show the opposite characteristics, with frequent $\mathrm{CD}$ in winter and hardly any $\mathrm{HD}$ in summer.

The small number of climatically uncomfortable days at Richards Bay throughout the year leads to relatively high CI values (average 7.8) with only small annual variations. The slightly higher number of HD from January to March produces slightly negative deviation of the CI in these months. Skukuza's relatively low CI (3.6) is almost entirely due to the high number of HD and it shows distinctively higher annual variations than Richards Bay. The CI is above average in the winter months from June to August as the number of HD is the smallest during this time. Port Elizabeth's relatively small number of HD in summer and the medium amount of $C D$ in winter lead to an average CI of 6.4 with slightly positive variations from November to April and negative variations from August to September. Pietersburg shows only small annual variations due to the decrease in the number of HD towards winter, which is accompanied by an increase in the number of $\mathrm{CD}$ and vice versa towards summer. The average CI of 4.9 shows slightly higher values in winter with a distinct optimum in May and slightly lower ones in summer. The transition from summer to winter and from winter to summer in Upington is very different from Pietersburg. The number of HD in Upington has decreased in spring but the number of CD has not yet increased and vice versa in autumn. This results in positive variations of the average CI of 5.8 in these times, whereas negative variations only occur in summer. Cape Agulhas shows a high number of CD and hardly any HD and with this opposite characteristics in comparison with Skukuza. The average CI of 5.9 is only approached in April and October, whereas the rest of the year shows extreme variations. Cape 
Agulhas provides almost optimum conditions in the summer months but very cold conditions in the winter months. Cape Town's conditions are similar to the ones in Cape Agulhas as far as the CD are concerned but the amount of HD in summer is distinctively higher. This produces an average CI of 4.7 with slightly positive variations in summer, optimum in April and negative variations in winter. Bloemfontein's thermal conditions are similar to Upington, but with a higher number of CD in winter which is responsible for strong negative variations from the average CI of 4.1 during this time.

Table IV shows the CI for all 31 cities and resorts. The annual CI values vary between approximately 8 (around six unpleasant days per month in average) at Port St. Johns, St. Lucia and Richards Bay to just above 3 (around 21 unpleasant days per month in average) in Fraserburg, Porterville, Skukuza and others. The CI in January and July varies between approximately 9 (less than three unpleasant days) and less than 1 (more than 27 unpleasant days). The most pleasant places in January are Cape Agulhas and Alexander Bay, the most unpleasant ones are Graaf Reinet, Kimberley and Porterville. Port Shepstone and Richards Bay head the list in July, at the bottom of the list are Fraserburg, Bethlehem and Johannesburg.

Figure 4 shows that the cities/resorts with the highest annual CI values are all located along the coast, where the influence of the water reduces the frequency of climatic extremes. The cities and resorts along the sub-tropical coast, which stretches from St. Lucia to Port Elizabeth, show the highest values in some

Table IV. CI of cities and resorts in South Africa

\begin{tabular}{|c|c|c|c|c|c|}
\hline Location & Rating & Location & Rating & Location & Rating \\
\hline Port St. Johns & 8.2 & Cape Agulhas & 9.5 & Port Shepstone & 9.0 \\
\hline St. Lucia & 7.8 & Alexander Bay & 8.5 & Richards Bay & 8.6 \\
\hline Richards Bay & 7.8 & East London & 8.5 & Durban & 8.2 \\
\hline East London & 7.4 & Port St. Johns & 8.2 & St. Lucia & 8.2 \\
\hline Alexander Bay & 7.1 & George & 7.9 & Nelspruit & 7.7 \\
\hline Durban & 6.8 & Cape Columbine & 7.6 & Port St. Johns & 7.2 \\
\hline Port Elizabeth & 6.4 & Port Elizabeth & 7.2 & Skukuza & 6.8 \\
\hline George & 6.0 & St. Lucia & 6.7 & Pietersburg & 6.1 \\
\hline Cape Agulhas & 5.9 & Richards Bay & 6.6 & Upington & 5.9 \\
\hline Upington & 5.8 & Cape Town & 5.4 & East London & 5.6 \\
\hline Nelspruit & 5.6 & Johannesburg & 5.2 & Graaf Reinet & 5.5 \\
\hline Port Shepstone & 5.6 & Durban & 4.8 & Pretoria & 4.8 \\
\hline Johannesburg & 5.3 & Fort Beaufort & 4.7 & Potchefstroom & 4.6 \\
\hline Bethlehem & 5.1 & Uitenhaage & 4.6 & Alexander Bay & 4.5 \\
\hline Potchefstroom & 5.1 & Bethlehem & 4.4 & Port Elizabeth & 4.3 \\
\hline Fort Beaufort & 4.9 & Port Shepstone & 3.8 & Uitenhaage & 4.1 \\
\hline Pietersburg & 4.9 & Nelspruit & 3.5 & Fort Beaufort & 4.0 \\
\hline Cape Town & 4.7 & Pietersburg & 3.2 & Kimberley & 4.0 \\
\hline Pretoria & 4.7 & Hawequas & 3.0 & George & 3.9 \\
\hline Uitenhaage & 4.7 & Malmesbury & 2.7 & Porterville & 3.4 \\
\hline Hawequas & 4.2 & Potchefstroom & 2.7 & Malmesbury & 2.3 \\
\hline Bloemfontein & 4.1 & Worcester & 2.3 & Grootfontein & 2.2 \\
\hline Grootfontein & 4.1 & Grootfontein & 2.0 & Cape Town & 2.0 \\
\hline Malmesbury & 4.0 & Pretoria & 2.0 & Worcester & 2.0 \\
\hline Worcester & 3.9 & Bloemfontein & 1.6 & Hawequas & 1.8 \\
\hline Cape Columbine & 3.8 & Skukuza & 1.6 & Cape Agulhas & 1.4 \\
\hline Kimberley & 3.8 & Upington & 1.6 & Bloemfontein & 1.3 \\
\hline Graaf Reinet & 3.7 & Fraserburg & 1.2 & Cape Columbine & 0.9 \\
\hline Skukuza & 3.6 & Porterville & 0.7 & Johannesburg & 0.8 \\
\hline Porterville & 3.3 & Kimberley & 0.6 & Bethlehem & 0.6 \\
\hline Fraserburg & 3.2 & Graaf Reinet & 0.5 & Fraserburg & 0.6 \\
\hline Entire year & & January & & July & \\
\hline
\end{tabular}


Table V. Monthly differentiation of the thermal bioclimatic conditions

\begin{tabular}{lllllllllllll}
\hline Location & 1 & 2 & 3 & 4 & 5 & 6 & 7 & 8 & 9 & 10 & 11 & 12 \\
\hline Alexander Bay & $\square$ & $\square$ & $\square$ & $\square$ & $\square$ & $\times$ & - & - & $\square$ & $\square$ & $\square$ & $\square$ \\
Bethlehem & + & $\times$ & $\square$ & $\square$ & - & - & - & - & $\square$ & $\square$ & $\square$ & $\square$ \\
Bloemfontein & + & + & + & $\square$ & $\square$ & - & - & - & $\times$ & $\times$ & + & + \\
Cape Agulhas & $\square$ & $\square$ & $\square$ & $\square$ & - & - & - & - & - & - & $\square$ & $\square$ \\
Cape Columbine & $\square$ & $\square$ & $\square$ & - & - & - & - & - & - & - & - & $\square$ \\
Cape Town & + & + & + & & - & - & - & - & - & $\times$ & $\square$ & $\square$ \\
Durban & + & + & + & + & $\square$ & $\square$ & $\square$ & $\square$ & $\square$ & $\square$ & $\square$ & $\square$ \\
East London & & & & & $\square$ & - & - & - & $\square$ & $\square$ & $\square$ & $\square$ \\
Fort Beaufort & + & + & + & $\times$ & $\square$ & - & - & - & $\times$ & $\square$ & $\times$ & + \\
Fraserburg & + & + & + & $\square$ & - & - & - & - & - & $\times$ & + & + \\
George & $\square$ & $\square$ & $\square$ & $\square$ & - & - & - & - & - & - & $\square$ & $\square$ \\
Graaf Reinet & + & + & + & + & & - & - & $\times$ & $\times$ & + & + & + \\
Grootfontein & + & + & + & $\square$ & - & - & - & - & $\times$ & $\times$ & $\times$ & + \\
Hawequas & + & + & + & $\square$ & - & - & - & - & - & - & $\square$ & + \\
Johannesburg & + & + & $\square$ & $\square$ & - & - & - & - & $\square$ & $\square$ & $\square$ & $\square$ \\
Kimberley & + & + & + & $\times$ & & - & - & - & $\times$ & + & + & + \\
Malmesbury & + & + & + & $\square$ & - & - & - & - & $\times$ & $\times$ & $\times$ & + \\
Nelspruit & + & + & + & $\square$ & $\square$ & $\square$ & $\square$ & $\times$ & + & + & + & + \\
Pietersburg & + & + & + & + & $\square$ & - & - & $\times$ & + & + & + & + \\
Port Elizabeth & $\square$ & $\square$ & $\square$ & $\square$ & $\square$ & - & - & - & - & $\square$ & $\square$ & $\square$ \\
Port Shepstone & + & + & + & + & + & $\square$ & $\square$ & $\square$ & $\square$ & $\times$ & + & + \\
Port St. Johns & $\square$ & $\square$ & $\square$ & $\square$ & $\square$ & $\square$ & $\square$ & $\square$ & $\square$ & $\square$ & $\square$ & $\square$ \\
Porterville & + & + & + & $\times$ & $\square$ & - & - & - & - & + & + & + \\
Potchefstroom & + & + & + & $\square$ & $\square$ & - & - & $\square$ & $\times$ & + & + & + \\
Pretoria & + & + & + & $\square$ & $\square$ & - & - & & + & + & + & + \\
Richards Bay & $\square$ & $\square$ & $\square$ & $\square$ & $\square$ & $\square$ & $\square$ & $\square$ & $\square$ & $\square$ & $\square$ & $\square$ \\
Skukuza & + & + & + & + & + & $\square$ & $\square$ & + & + & + & + & + \\
St. Lucia & $\square$ & + & $\square$ & $\square$ & $\square$ & $\square$ & $\square$ & $\square$ & $\square$ & $\square$ & $\square$ & $\square$ \\
Uitenhaage & + & + & + & + & $\times$ & - & - & - & $\times$ & $\times$ & + & + \\
Upington & + & + & + & $\square$ & $\square$ & - & - & $\square$ & $\square$ & $\square$ & + & + \\
Worcester & + & + & + & $\square$ & - & - & - & - & $\times$ & $\square$ & + & + \\
\hline & $\square$ & & + & $\square$
\end{tabular}

$\square$, pleasant conditions (less than 12 unpleasent days, CI $>6$ ); + , hot conditions (more than 12 hot days); - , cold conditions (more than 12 cold days); $\times$, hot or cold conditions (more than 12 days either hot or cold).

distance to the north and the south of Durban, whereas Durban itself as well as the nearby Port Shepstone show slightly worse conditions. Port Elizabeth's conditions as well as the conditions further south at the temperate coast, as represented by George, show also slightly worse conditions than Port St. Johns and East London. Conditions deteriorate with the distance to the sea as can be seen at the example of Uitenhage and Fort Beaufort. The cities and resorts in the mediterranean region (Cape Town, Cape Agulhas, Hawequas, Worcester, Malmesbury, Porterville and Cape Columbine) show very low annual CI values except of Cape Agulhas. The situation further north along the desert coast improve drastically from the bioclimatological point of view, as Alexander Bay belongs to the same group as Richards Bay, St. Lucia and East London. The worst annual CI values can be found in the semi-arid plateau (Upper Karoo, Great Karoo, Doring Karoo), represented by Fraserburg, Kimberley, Grootfontein and Graaf Reinet, and the sub-tropical lowveld, represented by Skukuza. Better bioclimatological conditions exist further north in the Bushmanland (Upington). The stations on the temperate eastern plateau (Bloemfontein, Bethlehem, Potchefstrom, Johannesburg, Pretoria and Pietersburg) as well as Nelspruit on the eastern plateau slopes show annual CI values that are in the middle of the range between the high values along the coast and the low values in the mediterranean region and the semi-arid plateau.

Figure 5 gives information about the months or seasons, when the thermal conditions in the cities and resorts are pleasant or unpleasant. The months have been differentiated whether they show more or less than 12 unpleasant days, where an unpleasant day is understood as either a hot or a cold day. According 
to this definition Port St. Johns, Richards Bay and St. Lucia (with exception in February), show pleasant conditions all year round. Alexander Bay, Port Shepstone and Durban have pleasant conditions mainly in the colder season, with hot conditions predominating the remainder of the time (see Table V). The resorts and cities further south along the coast down to Cape Agulhas have pleasant conditions in the warmer season with cold conditions in the winter months (Table V). Occasional pleasant months can be found in spring and autumn in the mediterranean region and in autumn on the semi-arid plateau. Some months in spring and autumn are rated as unpleasant months although they contain neither more than $12 \mathrm{HD}$ nor more than $12 \mathrm{CD}$, because the sum of HD and CD in these months exceeds the threshold value 12 (Table V). Pleasant months are more frequent in spring and autumn on the temperate eastern plateau. On the eastern plateau slopes (Nelspruit) and the eastern lowveld (Skukuza) pleasant months occur in winter.

\section{CONCLUDING REMARKS}

Wichmann et al. (1987) and Bucher (1992) show the connection between bioclimatic conditions and health risks and mortality. The rating of cities according to the CI as presented in this study enables the assessment of these risks and evaluation of the climatic aspect of the living quality of cities and resorts. Further research would be desirable to implement the aspect of the air quality in the CI and to apply the CI to other cities outside of South Africa.

\section{ACKNOWLEDGEMENTS}

The author wishes to thank the DAAD (Deutscher Akademischer Auslandsdienst) for funding the research, Professor Dr L. King (Department of Geography, Justus-Liebig University, Gießen, Germany) and Professor Dr P.D. Tyson (Climatology Research Group, University of the Witwatersrand, Johannesburg, South Africa) for their support and the South African Weather Service (Pretoria) for providing the climatic data.

\section{REFERENCES}

Ahlheim KH (ed.). 1989. Wetter und Klima. Meyers Lexikon Verlag: Mannheim-Wien-Zurich; 224.

Auliciems A, Kalma JD. 1979. A climatic classification of human thermal stress in Australia. Journal of Applied Meteorology 18: 616-625.

Becker S. 1996. Wärmebelastung in Israel. Quantifizierung, Regionalisierung und kurortklimatologische Analyse der thermischen Belastung des Menschen. Dissertation, Justus-Liebig Universität, Gießen.

Bucher K. 1992. Die Bedeutung des thermischen Wirkungskomplexes im Wirkungsakkord des Wetters am Beispiel von Todesfällen im Herz-Kreislaufbereich. Annalen der Meteorologie 28.

de Dear RJ, Brager G, Cooper D. 1997. Developing an adaptive model of the thermal comfort and preference. Final Report ASHRAE RP-884, March.

de Freitas CR. 1985. Assessment of human bioclimate based on thermal response. International Journal of Biometeorology 29: 97-119.

Fanger PO. 1972. Thermal Comfort: Analysis and Applications in Environmental Engineering. McGraw-Hill: New York.

Givoni B. 1976. Man, Climate and Architecture. Applied Science Publisher: London.

Ganong WF. 1971. Medizinische Physiologie. Springer: Berlin.

Hardy JD, Muschenheim C. 1934. The radiation of heat from the human body. Journal of Clinical Investigations 13 : 817.

Höppe P. 1984. Die Energiebilanz des Menschen. Wissenschaftliche Mitteilungen des Meteorologischen Institutes der Universität München; 49.

Hellmann G. 1917. Über die Bewegung der Luft in den untersten Schichten der Atmosphäre. (2. Mitteilung.). Meteorologische Zeitschrift 34: 273-285.

Jendritzky G, Sönning W, Swanter HJ. 1979. Ein objektives Bewertungsverfahren zur Beschreibung des thermischen Milieus in der Stadt- und Landschaftsplanung. Beiträge der Akademie für Raumforschung und Landesplanung: Hannover; 28.

Jendritzky G, Menz G, Schirmer H, Schmidt-Kessen W. 1990. Methodik zur räumlichen Bewertung der thermischen Komponente im Bioklima des Menschen. Beiträge der Akademie für Raumforschung und Landesplanung: Hannover.

Kasten F. 1989. Strahlungsaustausch zwischen Oberflächen und Atmosphäre. VDI Berichte, Nr. 721.

King E. 1951. Ein empirisches Schwülemaß. Medizin Meteorolog. Hefte Nr. 10.

Kleiber J. 1967. Der Energiehaushalt von Mensch und Haustier. Verlag Paul Parey: Hamburg. 
Leistner W. 1951. Die hygrische und klimatische Bedeutung des Dampfdrucks in Innenräumen und die Behaglichkeits- und Schwülegrenze. Medizin Meteorolog Hefte Nr. 6.

Mayer H. 1986. Stadtklima und seine humanbiometeorologische Bewertung. In Treffen Arbeitskreis Humanbiometeorologie, Mayer $\mathrm{H}$ (ed.). Wissenschaftliche Mitteilungen des Meteorologischen Institutes: München.

Mitchell D. 1970. Measurement of the thermal emissivity of human skin in vivo. In Physiological and Behavioral Temperature Regulation, Hardy JD (ed.). Charles T. Thomas: Illinois.

Oseland NA, Humphreys MA (eds). 1993. Thermal Comfort: Past, Present and Future. In Proceedings of a Conference Held at the Building Research Establishment, Garston, 9-10 June 1993. Building Research Establishment: Watford.

Paltridge GW, Platt CMR. 1976. Radiative Processes in Meteorology and Climatology, Development in Atmospheric Sciences 5. Elsevier Scientific: Amsterdam.

Scharlau K. 1950. Zur Einführung eines Schwülemaßstabes und Abgrenzung von Schwülezonen durch Isohygrothermen. Erdkunde 4: $188-201$.

Seidl H. 1990. Möglichkeiten und Probleme bei der humanbiometeorologischen Bewertung von Urlaubsklimaten am Beispiel der Mittelmeerländer. Diplomarbeit am Lehrstuhl für Geographie der Ludwig-Maximilian Universität München.

Sohar E. 1980. Determination and presentation of heat load in physiologically meaningful terms. Supplement to International Journal of Biometeorology 24: 1-8.

Terjung WH. 1966. Physiologic climates of the conterminous United States: a bioclimatic classification based on man. Annals of the Association of American Geographers 56: 141-179.

Thom EC. 1959. Discomfort index. Weatherwise 12: 57.

Weihe WH. 1985. Die Wetterfühligkeit als Diskomfort. Annalen der Meteorologie 22: 35-37.

Wichmann HE, Spix C, Mücke G. 1987. Kleinräumige Analyse der Smogperiode des Januar 1985 unter Berücksichtigung meteorologischer Einflüsse. Med. Inst. f. Umwelthygiene, Uni Düsseldorf. Auftrag d. Min. Arbeit, Gesundheit u. Soziales. NRW: Düsseldorf. 